\title{
MONITORING OF THE STATUS OF TOURISM AND RECREATION DEVELOPMENT IN UKRAINE
}

\author{
Oksana SYVAK \\ State Enterprise "Ukrainian State Scientific-Research Institute of Urban Design "Dipromisto" named after Y.M.Bilokon", Kyiv, Ukraine \\ syvak_ok@ukr.net
}

\begin{abstract}
The main trends in the tourism and recreation field development in Ukraine in 2014 are covered in the article. The monitoring of a situation in the field of recreation and tourism for the period since 2000 to 2014 is carried out. The points defined in urban planning documentation, namely in the General Scheme of Planning of the Territory of Ukraine. As for this moment due to the range of the objective reasons the planned indicators have not been reached reconsideration of the approaches and changes introducing to the main urban planning document of the state are necessary to be made. The further urban development policy in the field of improvement of tourism and recreational network in the country has to be directed at sustainable usage of territorial resources within each region. Negative and positive factors are defined and the direction of potential improvement of the tourism and recreation field development in Ukraine is represented in the article.

Key words: tourism, recreation, the General Scheme of Planning of the Territory of Ukraine, monitoring, urban planning documentation.
\end{abstract}

UDC: 711.25

\section{МОНІТОРИНГ СТАНУ РОЗВИТКУ ТУРИЗМУ ТА РЕКРЕАЦІї В УКРАÏНІ}

\author{
Оксана СИВАК \\ ДП уДНДІПМ «Діпромісто» імені Ю.М. Білоконя, м. Київ, Україна \\ syvak_ok@ukr.net
}

\begin{abstract}
Анотація: В роботі представлено основні тенденції розвитку галузі туризму та рекреації в Україні у 2014 році. 3дійснено моніторинг ситуації у галузі рекреації і туризму з 2000 року по 2014 рік. Представлено позиції закладені в містобудівній документації, а саме в Генеральній схемі планування території України. Оскільки, на даний час, з ряду об'єктивних причин ще не досягнуто запланованих показників, існує необхідність перегляду підходів та внесення змін до основного містобудівного документу держави. Подальшу містобудівну політику в галузі розвитку туристичної та рекреаційної мережі в країні доцільно спрямовувати на збалансоване використання територіальних ресурсів в межах кожного з регіонів. В статті визначені негативні і позитивні фактори, які впливають на галузь та відображено напрямки можливого удосконалення сфери туризму та рекреації в Україні.
\end{abstract}

Ключові слова: туризм, рекреація, Генеральна схема планування території України, моніторинг, містобудівна документація.

удк: 711.25

Постановка проблеми. Стаття розроблена на основі статистичної інформації Державного комітету статистики України, 1998-2015, без урахування інформації щодо тимчасово окупованої території Автономної Республіки Крим, м. Севастополя та частини території зони проведення антитерористичної операції.

Розвиток туристичної галузі значно впливає на розвиток економіки країни в цілому. Її визначальна роль полягає не тільки у фінансовому вкладі, а і у стимулюванні інших супутніх галузей, які виконують як допоміжну, так і самостійну функції.

У своїй промові Генеральний секретар ЮНВТО відзначив, що сектор туризму відіграє все більш і більш важливу роль у стимулюванні економічного зростання і розвитку міжнародної торгівлі, тому необхідно підняти його пріоритет і максимально використовувати відповідний потенціал.

За даними Всесвітньої туристичної організації на туризм припадає близько $10 \%$ виробленого у світі валового продукту та близько $30 \%$ світової торгівлі

(c) О. Сивак

послугами. Також ним акумульовано близько 7\% світових інвестицій, кожне 15 робоче місце, близько 5\% податкових надходжень. Кількість міжнародних туристичних мандрівок постійно зростає і відповідно доходи від готельно-туристичних послуг також підвищуватимуться до приблизно 2 трлн. дол. у 2020 р. (за припущеннями).

Наявні дані свідчать про те, що галузь туризму можна віднести до однієї із найперспективніших і привабливих для розвитку, в тому числі і в Україні.

Україна посідає одне $з$ провідних місць в Європі за рівнем забезпеченості цінними природними та історико-культурними ресурсами, здатними генерувати значний інтерес у вітчизняних та іноземних туристів, при цьому у 2014 році розвиток сфери туризму і рекреації України характеризувався негативною динамікою, зменшенням кількісних та якісних показників розвитку галузі. Що пов'язано як із зовнішніми, так і внутрішніми факторами.

На сучасному етапі туристична галузь України знаходиться під впливом негативних факторів, особливо це стосується агресії з боку Росії, окупованими територіями, проведенням бойових 
дій та, як наслідок, нестабільної політичної та економічної ситуації в державі, недосконалого механізму управління. Це приводить до гальмування інвестиційного клімату, неналежного фінансування, впливає на налагодження міжнародних зв'язків та розвиток туристичної індустрії взагалі. Головними зовнішніми факторами, які стримують розвиток туризму в Україні, $€$ нестабільність економікополітичної ситуації та млявість економічних реформ, несприятливість існуючих умов для підприємництва взагалі та туристичного зокрема, недосконалість i навіть певна агресивність нормативно-правового поля (i в тому числі - правил і умов перетинання кордонів іноземцями) i, як наслідок, відсутність необхідних інвестицій для розвитку туризму - як внутрішніх (через економічну кризу та бойові дії), так і іноземних (через несприятливий інвестиційний клімат). Несприятливість бізнесового клімату спричинила той факт, що 3 майже 3000 українських туристичних підприємств, які мають дійсні ліцензії на надання туристичних послуг, фактично на ринку працюють лише близько третини.

Виклад основного матеріалу. В державі спостерігалося зменшення показників динаміки туристичних потоків, при цьому виїзний туристичний потік, залишився орієнтовно на рівні 2013 року (у 2014 році становив 22,4 млн. осіб), за цей же період в'їзний туристичний потік зменшився майже в 2 рази порівнянні із аналогічним періодом (у 2014 році становив 12,7 млн. осіб), сальдо потоків відповідно також стало від'ємним і становило 9,7 млн. осіб із переважанням виїзного туристичного потоку (рис. 1).

Всього в 2014 році туристичними підприємствами України надано послуг 2,43 млн. туристів та 1,17 тис. екскурсантам.

При цьому в Україні за даними Держстату доходи суб'єктів туристичної галузі України у 2014 році знизилися на $15 \%$ порівняно з 2013 роком - до 5,566 мільярда гривень. За даними відомства, із загальної суми доходів 97,6\% (5,4 млрд. гривень) отримали юридичні особи, решта 2,4\% доходів (1339 млн. гривень) отримали фізичні особи-підприємці.
Мережа суб'єктів туристичної діяльності (юридичні та фізичні особи) в Україні у 2014 році зменшилася майже на 70\% у порівнянні із 2013 роком та становила 3,9 тис. одиниць у порівнянні iз 2014 роком - 5,7 тис. одиниць. При цьому в структурі мережі за видами туристичної діяльності найчисленніша категорія - турагенти $(79 \%$ від загальної кількості суб’єктів), найменша категорія - суб’єкти, що здійснюють екскурсійну діяльність - 3,8\%. У структурі юридичних осіб, які здійснювали туристичну діяльність минулого року, 30\% склали туроператори (667 суб'єктів), $67 \%$ - турагенти (1473 суб'єктів) і лише $2,6 \%$ - суб'єкти, які здійснюють екскурсійну діяльність (лише 58 суб'єктів).

За географічними напрямами туристичні потоки мають наступну орієнтацію: Єгипет, Туреччина, Болгарія, Греція, Об'єднані Арабські Емірати, Іспанія, Польща, Чехія, Шрі-Ланка, Російська Федерація, Кіпр тощо.

До України приїздили переважно з Азербайджану, Російської Федерації, Молдови, Білорусії, Польщі, Болгарії, Грузії, Німеччини, Туреччини та США. Незважаючи на широку “географію” туристів, які приїжджають до нашої країни, їх переважну частину (78\%) складають туристи 3 колишнього СРСР, і в першу чергу - 3 Азербайджану, Росії, Білорусії, Туркменістану. Щодо інших країн, то найбільше Україну відвідують туристи з Угорщини, Словаччини та Польщі. При цьому частина іноземних туристів, які подорожували в туристичних групах, $\epsilon$ досить незначною - лише 1,2\%. Більшість громадян, які, за існуючою класифікацією, розглядаються як іноземні туристи, фактично такими не $\epsilon$, а відвідують Україну зі службовими або приватними цілями. Це водночас є яскравим свідченням недостатності розвитку в Україні організованого туризму.

Кількість в'їзних (іноземних) туристів становила 17,0 тис. осіб, що майже на $70 \%$ менше показників 2013 року (232,0 тис. осіб). Що пов’язано із ситуацією, яка склалася в Україні.

Кількість виїзних туристів, як було вказано вище, становила 2,08 млн. осіб, з яких більша частина виїзних туристів припадає на м. Київ.

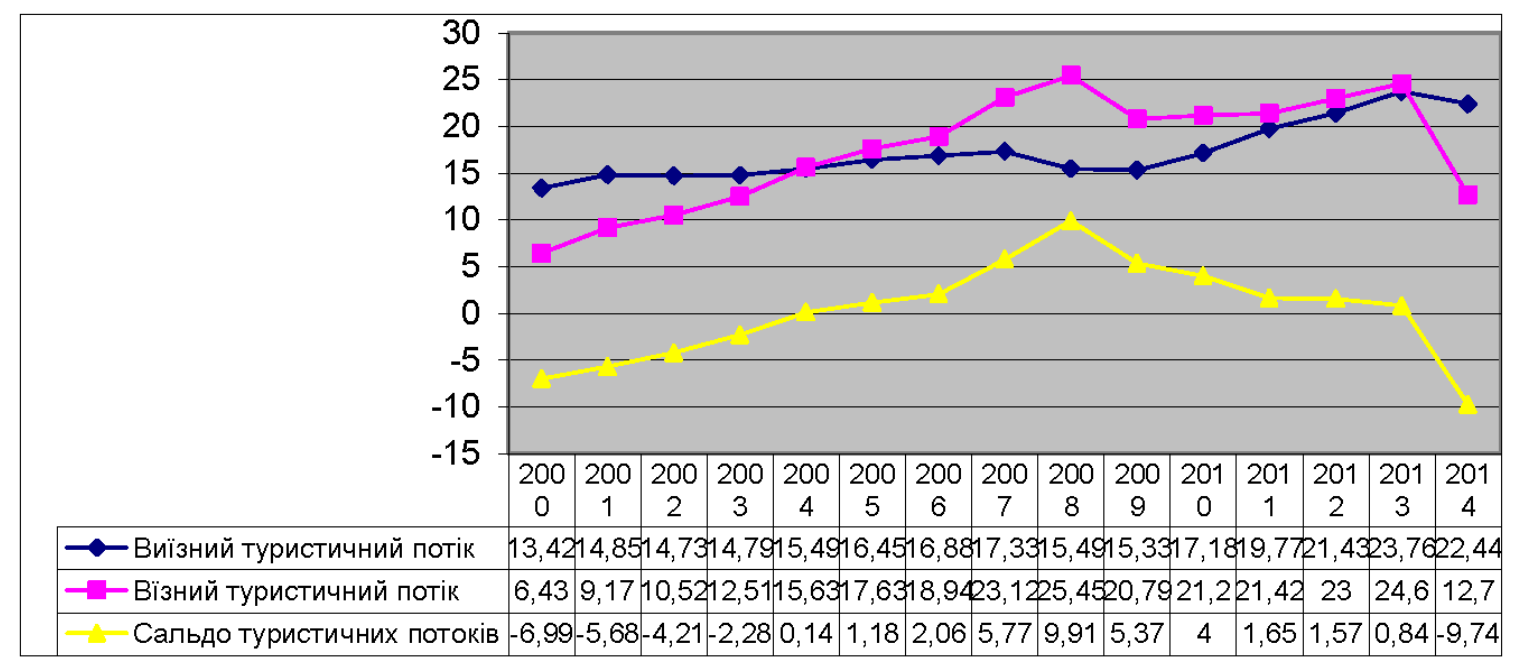

Рис. 1. Динаміка туристичних потоків в Україні 2000-2014 роки, млн. осіб 
Туристи, обслуговувані суб’єктами туристичної діяльності України (тис. осіб)

\begin{tabular}{|c|c|c|c|c|}
\hline \multirow[b]{2}{*}{ Роки } & \multirow{2}{*}{$\begin{array}{c}\text { Кількість туристів, обслугованих } \\
\text { суб’єктами туристичної діяльності } \\
\text { України - усього }\end{array}$} & \multicolumn{3}{|c|}{ Із загальної кількості туристів : } \\
\hline & & $\begin{array}{c}\text { іноземні } \\
\text { туристи }\end{array}$ & $\begin{array}{c}\text { туристи-громадяни } \\
\text { України, які виїжджали } \\
\text { за кордон } \\
\end{array}$ & $\begin{array}{c}\text { внутрішні } \\
\text { туристи }\end{array}$ \\
\hline 2000 & 2014 & 378 & 285 & 1351 \\
\hline 2005 & 1826 & 327 & 567 & 932 \\
\hline 2006 & 2206 & 299 & 868 & 1039 \\
\hline 2007 & 2864 & 372 & 336 & 2155 \\
\hline 2008 & 3042 & 373 & 1282 & 1387 \\
\hline 2009 & 2290 & 282 & 914 & 1094 \\
\hline 2010 & 2281 & 336 & 1296 & 649 \\
\hline 2011 & 2200 & 234 & 1250 & 716 \\
\hline 2012 & 3001 & 270 & 1957 & 774 \\
\hline 2013 & 3454 & 232 & 2519 & 703 \\
\hline 2014 & 2425 & 17 & 2085 & 323 \\
\hline
\end{tabular}

Згідно інформації представленої Державним комітетом статистики України, 1998-2015

Таблиия 2

Діяльність колективних засобів розміщування у 2014 році

\begin{tabular}{|c|c|c|c|}
\hline & $\begin{array}{c}\text { Кількість } \\
\text { колективних } \\
\text { засобів } \\
\text { розміщування, } \\
\text { одиниць }\end{array}$ & $\begin{array}{l}\text { Кількість місць, } \\
\text { одиниць }\end{array}$ & $\begin{array}{c}\text { Кількість } \\
\text { розміщених, осіб }\end{array}$ \\
\hline $\begin{array}{l}\text { Колективні засоби розміщування, всього, в } \\
\text { тому числі }\end{array}$ & 4572 & 407975 & 5424040 \\
\hline $\begin{array}{l}\text { Готелі та аналогічні засоби розміщування, } \\
\text { всього, із них: }\end{array}$ & 2645 & 135391 & 3813970 \\
\hline готелі & 1523 & 99059 & 3194073 \\
\hline мотелі & 138 & 3685 & 103941 \\
\hline хостели & 28 & 1248 & 37820 \\
\hline кемпінги & 11 & 319 & 10036 \\
\hline гуртожитки для приїжджих & 118 & 8045 & 113414 \\
\hline $\begin{array}{l}\text { туристські бази, гірські притулки, } \\
\text { студентські літні } \\
\text { табори, інші місця для тимчасового } \\
\text { розміщування }\end{array}$ & 827 & 23035 & 354686 \\
\hline $\begin{array}{l}\text { Спеціалізовані засоби розміщування, всього, } \\
\text { iз них }\end{array}$ & 1927 & 272584 & 1610070 \\
\hline санаторії & 187 & 58527 & 544932 \\
\hline дитячі санаторії & 117 & 17952 & 124704 \\
\hline пансіонати з лікуванням & 17 & 2863 & 17034 \\
\hline $\begin{array}{l}\text { дитячі заклади оздоровлення цілорічної дії, } \\
\text { дитячі центри }\end{array}$ & 16 & 5733 & 37418 \\
\hline санаторії-профілакторії & 118 & 17407 & 99899 \\
\hline $\begin{array}{l}\text { бальнеологічні лікарні, грязелікарні, } \\
\text { бальнеогрязелікарні (включаючи дитячі) }\end{array}$ & 3 & 690 & 3187 \\
\hline будинки відпочинку & 17 & 1470 & 10396 \\
\hline пансіонати відпочинку & 73 & 15836 & 71149 \\
\hline $\begin{array}{l}\text { бази відпочинку, інші заклади відпочинку } \\
\text { (крім турбаз) }\end{array}$ & 1367 & 150828 & 697100 \\
\hline оздоровчі заклади 1-2 денного перебування & 12 & 1278 & 4251 \\
\hline
\end{tabular}

Згідно інформації представленої Державним комітетом статистики України, 1998-2015 
Кількість внутрішніх туристів становила 322,0 тис. осіб, що на $50 \%$ менше показників 2013 року.

Переважна більшість туристів віддають перевагу приватним туристичним подорожам.

За даними Держкомстату, упродовж 2014 року в Україні працювало 4572 колективних засобів розміщування (юридичні особи та фізичні особипідприємці), що на 1839 закладів (30\%) менше, порівняно $з$ попереднім роком. Кількість місць зменшилася на 178,0 тисяч і склала 407,9 тис. одиниць. Спостерігається зменшення кількості розміщених у колективних засобах розміщування з 8303,0 тис. осіб 2013 році до 5424,0 тис. осіб у 2014 році (65\%). Серед розміщених осіб 10,2\% становили іноземці.

У таблиці 2 представлено діяльність колективних засобів розміщування у 2014 році.

В Україні наявні різноманітні курортні ресурси та існує розвинута мережа санаторно-курортних установ, великий науковий та практичний досвід роботи персоналу.

У 2014 році в Україні функціонувало 187 санаторіїв та 17 пансіонатів 3 лікуванням, 118 санаторіїв-профілакторіїв, 73 пансіонати та будинків відпочинку, 1367 бази та інших закладів відпочинку та заклади 1-2 денного перебування із загальною кількістю місць 407 тисяч. Загалом санаторнокурортні та оздоровчі заклади в 2014 році відпочили 1,6 млн. осіб, з яких у санаторіях - 545,0 тис. осіб, дитячих санаторіях - 125,0 тис. осіб базах та інших закладах близько 930,0 тис. осіб. В цілому у порівнянні із 2013 роком статистична звітність констатує зменшення на 70\% кількості спеціалізованих засобів розміщення (санаторії, пансіонати, бази відпочинку тощо), що спровоковано анексією та окупацією, бойовими діями в Україні та негативно відзначилося, як на галузі рекреації та туризму так i на економіці країни в цілому. Адже діяльність санаторно-курортних установ має велике соціальне значення для працевлаштування населення, як на самих об'єктах санаторно-курортної діяльності, так і в обслуговуючих господарствах.

В Україні немає повного кадастру земель оздоровчого i рекреаційного призначення; не встановлені проектні межі охоронних зон всіх видів (зон санітарної охорони курортів, прибережних захисних смуг вздовж морів тощо); не визначені в умовах роздержавлення та розпаювання земель показники резервних рекреаційних територій i юридично не оформлені як землі запасу рекреаційного призначення.

Містобудівна політика та перспективи розвитку галузі відповідно до Генеральної схеми планування території України. Відповідно до Генеральної схеми планування території України, на першому етапі (у період до 2010 р.) згідно прогнозу, місткість оздоровчих та рекреаційних закладів мала збільшитись до 1009,0 тис. місць, що в середньому у 1,2 рази більше порівняно з фактичною місткістю на 01.01.2000 року (близько 800,0 тис. місць). Це було обгрунтовано розрахунковими даними Держкоммолодьспорттуризму та $\mathrm{AO}$
«Укрпрофоздоровниця» стосовно розвитку мережі оздоровчих та рекреаційних закладів до 2010 року. Запланованого зростання не відбулося, у 2010 р. місткість санаторно-оздоровчих і курортних закладів становила 449,0 тис ліжок, місткість закладів готельного господарства - 79,8 тис. місць.

На другому етапі (у період до 2020 року) місткість оздоровчих i рекреаційних закладів прогнозується збільшити у 2,0-2,3 рази і довести до 1833,0 тис. місць. Передбачалося нове будівництво курортних та туристських готелів 3,4,5 - зіркового стандартів, житла нового типу, розрахованого на прийом туристів, приватних пансіонатів, міні-готелів тощо, а також подальший розвиток садово-дачного будівництва. Це період здійснення численних інвестиційних програм для формування сучасної інфраструктури 3 метою активізації розвитку міжнародного туризму. Розвиток зон масового відпочинку передбачається довести до 12572,0 тис. чоловік.

На третьому етапі (на більш далеку перспективу) передбачається збільшення місткості оздоровчих і рекреаційних закладів та зон масового відпочинку у 2,1-3 рази і більше. Поряд з подальшим розвитком будівництва різних видів оздоровчих та рекреаційних закладів активно розвиватимуться форми відпочинку населення в умовах природного середовища - екологічний туризм, сільський відпочинок тощо. Це період досягнення збалансованого розвитку системи оздоровчих i рекреаційних закладів та зон масового відпочинку для задоволення як внутрішніх потреб населення, так і міжнародного попиту.

В зв'язку із тим, що не досягнуто показників закладених Генеральною схемою планування території України на перспективу необхідно переглянути показники закладені в Генеральній схемі планування території України.

Враховуючи, що рекреаційні потреби на даному етапі сформовані, головними заходами є: реструктуризація існуючої мережі закладів, ïx реконструкція, перепрофілювання i повільне зростання згідно економічних можливостей.

Подальшу містобудівну політику в галузі розвитку оздоровчої та рекреаційної мережі в країні доцільно спрямовувати на збалансоване використання територіальних ресурсів в межах кожного 3 регіонів, а також на більш активний розвиток Карпатського, Причорноморського, Поліського, Східного регіонів.

Можна виділити декілька важливих та актуальних напрямків, щодо перспектив розвитку курортно-рекреаційної галузі та туризму в Україні, a саме:

сталий, стабільний розвиток, мир і спокій в державі;

необхідність визнання на державному рівні пріоритетів розвитку рекреації та туризму;

якісна й економічно адекватна транспортна інфраструктура, як складова розвитку сфери туризму та рекреації;

надання якісних медичних послуг 
санаторно-курортної системи; інформаційна підтримка та пропаганда відпочинку та оздоровлення населення власне на території нашої держави, а не поза її межами; подальший розвиток дитячого i молодіжного туризму, як частини виховання й оздоровлення підростаючого покоління та однієї iз найбільших у світі інфраструктури дитячого відпочинку, а також раціональне використання спортивної інфраструктури в рекреації, а значить - у туризмі;

необхідність будівництва нових рекреаційних закладів, що відповідають міжнародним вимогам для активізації іноземного туризму, а також створення осередків екологічного, сільського, зеленого туризму для залучення широкого кола любителів природи.

Аналізуючи можливості із розвитку туризму в Україні можна виділити ряд позитивних та негативних чинників, які впливають на ситуацію у сфері туризму.

До чинників, які негативно впливають на розвиток галузі туризму в Україні в 2014 році можна віднести:

- економічна ситуація, анексія Криму, окупація частини територій нашої держави та проведення антитерористичної операції;

- незадовільний стан туристичної, сервісної i інформаційної інфраструктури в зонах впливу автомобільних доріг і міжнародних транспортних коридорів;

- значне навантаження на Причорноморські території нашої держави (Одеська, Херсонська, Миколаївська області), які в 2014 році в зв'язку із анексією Криму прийняли на себе навантаження в курортний сезон та виявилися не готовими до такої кількості туристів;

- неефективне та нераціональне використання природних ресурсів;

- недостатньо розвинена інфраструктура, а також система транспортного обслуговування туристів та населення;

- питання якості надання туристичних послуг;

- недостатня поінформованість населення про готелі, інші заклади відпочинку, тури по країні, туристичні послуги;

До позитивних чинників, які впливають на розвиток туризму в Україні можна віднести:

- наявність значного туристично-рекреаційного потенціалу та можливостей його використання для потреб внутрішніх та іноземних туристів;

- існування значного потенціалу споживачів, які за сприятливих умов та можливостей формуватимуть попит на задоволення потреби у відпочинку за рахунок внутрішнього туризму;

- можливості для розбудови та створення інфраструктури туризму для задоволення зростаючих потреб туристів;

У світовому масштабі позиції туристичної галузі у 2014 році не змінилися, лідерами є Свропа, Азіатсько-Тихоокеанський і Американський регіони, показники доходів дозволяють продовжити ланку
Близьким Сходом i Африкою. Це пояснюється відповідним відношенням і наданням особливого статусу туристичній галузі. Звичайно найвищі показники мають регіони з багатими природними та історико-культурними ресурсами, зі зручним географічним положенням, 3 належним фінансуванням, 3 постійним удосконаленням системного підходу до управління туристичною галуззю державних органів, науковців - економістів i аналітиків, бізнес-еліти, 3 підтриманням позитивного інвестиційного клімату.

Україна має всі потенційні можливості для розвитку туристичної галузі як у напрямку відпочинку і оздоровлення, так і у напрямку підвищення інтелектуальних можливостей і культурного рівня людини. Все це можуть забезпечити унікальні природно-кліматичні, історичні, культурні та етнографічні ресурси. Великий вклад мають регіони Північного Приазов'я, Карпат, з величезною вірою на возз'єднання необхідно назвати Крим, а також багаті на історичні пам'ятки і культурну спадщину українські міста.

Подолання наявних негативних тенденцій, створення системних та комплексних передумов для сталого розвитку туризму має стати одним 3 пріоритетних напрямів забезпечення сталого розвитку країни в цілому та суттєвою складовою у вирішенні питань підвищення якості життя населення.

Висновки. Розвиток сфери туризму і рекреації в Україні у 2014 році характеризувався негативною динамікою у зв'язку 3 нестабільною політичноекономічною ситуацією в країні. При цьому продовжують зберігатися такі негативні фактори розвитку галузі, як незадовільна якість обслуговування туристів, недостатньо розвинена інфраструктура та система транспортного обслуговування туристів і населення, низька поінформованість щодо туристично-рекреаційних пропозицій в Україні. Разом 3 тим, зважаючи на історико-культурний та природний потенціал території України, а також на світові тенденції розвитку туристично-рекреаційної галузі, очевидним є іiі значення для економіки нашої держави.

Ключовими кроками до забезпечення ефективного розвитку туристично-рекреаційної галузі в Україні $є$ вдосконалення існуючої законодавчої бази $з$ метою формування сприятливого інвестиційного клімату; розроблення містобудівної документації для забезпечення сталого розвитку територій потенційно придатних для розміщення об'єктів туризму та рекреації, в першу чергу - вздовж Чорноморського узбережжя, яке наразі зазнає значного перевантаження i процесів неузгодженої розбудови у зв'язку із анексією Криму; розроблення довгострокової програми розвитку та вдосконалення сфери туризму і рекреації $з$ метою визначення та підтримки пріоритетних видів туризму і рекреації та відповідних територій. 


\section{References:}

1. Bìlokon' Û. M. Regional'ne planuvannâ (teoriâ ì praktika) [Regional planning (theory and practice)]. Ed. I.O. Fomin. Kyiv, 2003, 246 p. (In Ukrainian).

2. General'na shema planuvannâ teritoriï Ukraïni [General Scheme for Planning of the Territory of Ukraine]. Kyiv: State Committee of construction, architecture and housing policy of Ukraine, Ukrainian State ScientificResearch Institute of Urban Design "Dipromisto", 2000, 112 p. (In Ukrainian).

3. Ozdorovlennâ ditej u ditâčih zakladah ozdorovlennâ ta vìdpočinku vlitku 2014 roku. Statističnij bûleten' [Health improvement of children in children's institutions of health improvement and rest in the summer of 2014. Statistical Bulletin]. Ed.: O. O. Karmazìn, 2014, 57 p. (In Ukrainian).

4. Ukraïna u cifrah u 2014 rocì. Statističnij zbirnik [Ukraine in figures: 2014. Statistical compendium]. Ed.: İ. M. Žuk, 2015, 235 p. (In Ukrainian). 